\title{
En torno a Rodrigo Cota y la autoría de las Coplas del provincial
}

\author{
Jesús Fernando Cáseda Teresa* \\ I.E.S. Valle del Cidacos - Calahorra (La Rioja) \\ ORCID ID: https://orcid.org/0000-0003-0409-4297
}

En este estudio se atribuye la autoría de las Coplas del provincial a Rodrigo Cota. Establezco dicha autoría a partir de lo que dice Juan Álvarez Gato en un poema y de las abundantes referencias a la familia de Pedrarias Dávila, cuñado de Cota, que hallamos en el texto. Pongo en relación las Coplas del provincial con las obras que conocemos de Rodrigo Cota, y encuentro interesantes coincidencias. Establezco la causa de la escritura de las Coplas del provincial (sentencia arbitral de Medina del Campo), tras situar el espacio (Madrid) y tiempo (primavera de 1465) del poema.

Palabras Clave: Poesía del siglo xv; Coplas del provincial; Rodrigo Cota; judeoconverso; sentencia arbitral de Medina del Campo.

Around Rodrigo Cota and the Authorship of the Coplas del Provincial.This study attributes the authorship of the Coplas del provincial to Rodrigo Cota. I establish this authorship from what Juan Álvarez Gato says in a poem and from the abundant references to the family of Pedrarias Dávila, Cota's brother-in-law, which we find in the text. I relate the Coplas del provincial with the works we know of by Rodrigo Cota, and I find interesting coincidences. I establish the cause of the writing of the Coplas del provincial (Medina del Campo arbitration award), after locating the space (Madrid) and time (spring 1465) of the poem.

KeYwords: 15th century poetry; Coplas del provincial; Rodrigo Cota; judeo-convert; Medina del Campo arbitration award.

* casedateresa@yahoo.es.

Copyright: (C) 2019 CSIC. Este es un artículo de acceso abierto distribuido bajo los términos de la licencia de uso y distribución Creative Commons Reconocimiento 4.0 Internacional (CC BY 4.0). 


\section{FECHA DE ESCRITURA DE LA OBRA, LOCALIZACIÓN Y ESTRUCTURA}

La mayor parte de la crítica data las Coplas del provincial entre 1465 y 1474. De esta opinión son Menéndez Pelayo ${ }^{1}$, Celestino López y Francisco Torrecilla ${ }^{2}$. Idea compartida asimismo por Julio Rodríguez Puértolas ${ }^{3}$. Hay, sin embargo, algunos detalles que nos permiten situarla con mayor precisión. Para establecer el terminus ad quem, hemos de tener en cuenta la alusión en la obra, como personas vivas, a don Pedro Girón -el cual falleció en $1466^{4}$ - y a Diego Arias Dávila, que murió en enero del mismo año, $1466^{5}$. Por tanto, la obra se escribió, como muy tarde, en diciembre de 1465.

Para establecer un terminus a quo, hemos de tener en cuenta que en la obra se alude al duque de Alburquerque, cuyo título otorgó Enrique IV de Castilla en Real Cédula de 26 de septiembre de 1464 a su valido don Beltrán de la Cueva ${ }^{6}$. De manera que este sería un terminus a quo perfectamente válido.

Por tanto, casi con total seguridad, la obra se escribió en el año 1465. Y dicho año fue muy importante en el desarrollo de la política del rey Enrique, pues se produjo la llamada farsa de Ávila -5 de junio- por la que una serie de nobles junto con el arzobispo de Toledo, Alonso Carri1lo, destronaron a un figurón de rey, o rey en efigie, simbolizando a

1 Marcelino Menéndez Pelayo, Historia de la poesía castellana en la Edad Media (Madrid: Librería General de Victoriano Suárez, 1914) págs. 296-298.

2 Celestino López Álvarez y Francisco Torrecilla del Olmo, «El autor, sus pretensiones y otros aspectos de las Coplas del Provincial», Bulletin Hispanique 83 (1981) págs. 237-262: 247.

3 Julio Rodríguez PuÉrtolas (ed.), Poesía crítica y satírica del s. XV (Madrid: Castalia, 1981) pág. 235.

4 Joseph O'Callaghan, «Don Pedro Girón, Master of the Order of Calatrava (14451466)», Hispania: Revista Española de Historia 83 (1961) págs. 342-390: 342.

5 María Eugenia Contreras JimÉnEz, Linaje y transición histórica: los Arias Dávila entre el medievo y la modernidad (Madrid: Universidad Complutense, 2018).

6 Alfonso Franco Silva, Estudios sobre Don Beltrán de la Cueva y el Ducado de Alburquerque (Badajoz: Universidad de Extremadura, 2002). 
Enrique IV, y proclamaron como su sustituto a su hermano pequeño, Alfonso el Inocente 7 .

Las Coplas del provincial no aluden, sin embargo, a hechos tan importantes -que sin duda hubieran salido a relucir en texto tan mordaz-, por lo que hemos de concluir que se escribieron en fechas anteriores al mes de junio del año 1465: en consecuencia, entre enero y mayo. Si tenemos en cuenta, además, que en la obra se alude a «aqueste invierno» como tiempo relativamente próximo («bien lo sabe el Provincial, / porque desde aqueste invierno / yo y el nuestro mayoral / andamos a toma el cuerno») ${ }^{8}$, podemos llegar a la siguiente conclusión: la obra debió de escribirse entre marzo y mayo de 1465.

El autor se refiere hasta en tres ocasiones a la $\left\langle\right.$ villa ${ }^{9}{ }^{9}$ como lugar donde se sitúan el rey y sus cortesanos y, a este respecto, tengo pocas dudas de que se trata de Madrid. La razón es que entonces era un lugar donde acostumbraban a acudir los nobles acompañando al rey en sus frecuentes estancias en la ciudad precapitalina. Sabemos que en 1465 estuvo en marzo y abril en la localidad madrileña. Por tanto, la obra se compuso en dichas fechas, con ocasión del tiempo en que Enrique IV y su séquito cortesano permanecieron allí. Los otros espacios que competían con Madrid, como estancias reales, fueron Segovia y Toledo. Pero en la obra se alude en un momento a «los de Toledo» ${ }^{10}$ como recién venidos y seguidamente se señala que «los de Segovia han llegado» ${ }^{11}$. Y ello ya nos está indicando que no nos encontramos ni en una ni en otra, sino en Madrid. Será, por otra parte, la última de una serie de estancias regulares en la ciudad, pues a partir de la rebelión de su hermano Alfonso estas se espaciarán reduciéndose muchísimo. Según Óscar Perea Rodríguez, el monarca «veía en la ciudad [Madrid] un lugar de reposo y de divertimento a la que apenas pudo acudir durante los años de de-

7 José Luis Martín, Enrique IV de Castilla: Rey de Navarra, Príncipe de Cataluña (Hondarribia: Nerea, 2003) pág. 128.

${ }^{8}$ Rodríguez Puértolas (ed.), Poesía crítica y satírica del s. $X V$, pág. 252.

9 Rodríguez PuÉrtolas (ed.), Poesía crítica y satírica del s. XV, págs. 238, 246 y 252 .

10 Rodríguez PuÉrtolas (ed.), Poesía crítica y satírica del s. XV, pág. 254.

11 Rodríguez Puértolas (ed.), Poesía crítica y satírica del s. XV pág. 254. 
clive de su reinado» ${ }^{12}$ a partir precisamente de 1465 en que se escribieron las Coplas del provincial.

Hemos de mirar en tal sentido la obra como reflejo del último momento de tranquilidad en el reinado de Enrique IV, el cual no había sido un mal gobernante durante su primer decenio al frente del país, según señala Azcona ${ }^{13}$. Las cosas cambiarán mucho a partir de aquel año 1465 en que se escribieron las Coplas del provincial.

José María Díez Borque dijo que las Coplas del provincial no tienen ni orden ni concierto «ni el menor propósito de ordenación» ${ }^{14}$ y que existe un caos estructural considerable. Sin embargo, tal caos no es tan evidente por lo que a continuación señalo. La obra se estructura en base a una alegoría: un provincial o visitador de una orden religiosa acaba de llegar a la corte donde se sitúa el monasterio (Castilla) y pasa revista a los frailes y mujeres -que no monjas- que allí se encuentran. Su actitud es a la vez inquisidora, haciendo preguntas, y acusadora. No hay desarrollo narrativo de ninguna clase, pues no hay historia; pero, a cambio, sí existe una estructura, básicamente descriptiva, basada en una doble jerarquía: hombres y mujeres por un lado; estructura piramidal estamental por la otra. Así, los individuos -reales con su nombre o aludidos, pero siempre referidos a seres de carne y hueso- se organizan jerárquicamente.

Los primeros que desfilan en la obra son, en este orden, el rey, el marqués de Cañete y el duque de Alburquerque, los más próximos a Enrique IV y los más poderosos. A continuación, figuran el duque Cascorvillo (Beltrán de la Cueva), conde de Benavente, conde de Ribadeo, de Rojas, etc. que conforman un segundo nivel en este orden estamental. El tercero lo constituyen los clérigos y señores que tienen alguna relevancia: prior de León, Alonso de Aguilar, Cristóbal Platero, Álvaro Pérez de Castro, Diego Arias, Alonso de Torres, Diego de Ayala, Gil

12 Óscar PereA, «Juan Álvarez Gato en la villa y corte literaria del Madrid tardomedieval», en La villa y la tierra de Madrid en los Albores de la capitalidad (siglos XIVXVI), ed. Eduardo JimÉnez RAYADo (Madrid: Almudayna, 2010) págs. 49-77: 64.

13 Tarsicio de Azcona, Isabel La Católica: Estudio crítico de su vida y su reinado (Madrid: La Esfera de los Libros, 2002).

14 José María Díez Borque, Historia de la literatura española. La Edad Media (Madrid: Taurus, 1980) pág. 267. 
González de Bobadilla, etc. Y, finalmente, las mujeres, desde una innominada «Marquesa» hasta Aldonza de Valdés, en un orden estamental también jerarquizado.

De manera que no podemos decir que las Coplas del provincial no tienen una estructura organizada, pues básicamente el orden lo dan el sexo y el nivel estamental de cada uno de los individuos que allí aparecen. Lo que sí que echamos en falta es una conclusión o cierre. Y una declaración de su autor sobre cuál ha sido el objeto último de su mordaz sátira, de la que ninguno de los citados en la obra se libra.

\section{LA AUTORÍA DE LA OBRA}

La cuestión de la autoría de las Coplas del provincial se ha venido planteando desde el mismo momento de su salida a la luz cuando se difundieron, en forma anónima y manuscrita, bajo prohibición inquisitorial. Han sido diversos los debates que se han abierto y, resumidamente, se han atribuido hasta a cinco autores: Antón de Montoro, Fernando del Pulgar, Alonso de Palencia, Rodrigo Cota y fray Íñigo de Mendoza ${ }^{15}$. Detrás de cada una de las atribuciones hay argumentos de interés y otros que no se sostienen en exceso. Por ejemplo, de los cinco señalados, solo de tres sabemos a ciencia cierta que escribieron poesía: Montoro, Cota y fray Íñigo de Mendoza. Aunque ello no invalida al resto como posibles autores, ciertamente los coloca en desventaja respecto a los otros tres. Estos últimos son contemporáneos de la obra y cualquiera sería un buen candidato.

15 Marcelino Menéndez Pelayo (Historia de la poesía castellana en la Edad Media, tomo II, págs. 298 y 299) considera que Alonso de Palencia no es un buen candidato, puesto que no conservamos ningún verso suyo y solo obras en prosa. A Cota en ningún caso, según su parecer, podrían atribuírsele las Coplas del provincial, puesto que su única obra entonces conocida, Diálogo entre el amor y un viejo, nada tiene que ver con aque1la. Finalmente, como luego señalo, apostará por una autoría colectiva. Raymond FoulChÉ Delbosc («Notes sur las Coplas del Provincial» Revue Hispanique 6 [1899] págs. 417-446: 428) apunta a Cota aunque con prevenciones. Más tarde, José AmADOR DE Los Ríos (Historia crítica de la literatura española [Madrid: Imprenta a cargo de José Fernández Cancela, 1863] vol. 7, pág. 129) y otros concluyeron -como luego señalo-, siguiendo la idea de Menéndez Pelayo, que quizás se trate de una obra escrita en forma colaborativa. 
Fray Iñigo de Mendoza no lo es. Basta con acercarse, siquiera someramente, a la Vita Christi ${ }^{16}$ para darse cuenta de que poco tiene que ver con las Coplas del provincial. Si bien es cierto que la obra de Mendoza incluye alguna sátira del rey Enrique IV, y que en ella hallamos muestras de un lenguaje popular, no alcanza su lengua el nivel de crueldad de aquellas. Ni tampoco su crítica se dirige indiscriminadamente a tantos individuos, perfectamente identificables, como ocurre en las Coplas del provincial.

Al caso de Antón de Montoro, escritor cordobés cercano al círculo de escritores de Jaén, con Hernán Mexía y Pedro de Escavias, me referiré a lo largo de este apartado; pero baste con señalar que, entre los poemas que de él conservamos, recogidos y publicados por Julio Rodríguez Puértolas y Marcela Ciceri ${ }^{17}$, así como también por Francisco Cantera Burgos y Carlos Carrete Parrondo ${ }^{18}$, hay multitud de composiciones que muestran su relación con el Marqués de Santillana, con Juan de Mena y con buena parte de la nobleza castellana, incluyendo a la propia reina Isabel la Católica. Pese a tener un trabajo humilde -ropero o sastre - fue miembro de una familia distinguida de la ciudad de Córdoba y mantuvo una excelente relación con el poder tanto durante el período del reinado de Enrique IV como bajo el gobierno de su hermanastra la reina Isabel. Entre sus composiciones, abundan las encomiásticas, aduladoras, sin rastro alguno de la sátira que podemos encontrar en las Coplas del provincial.

A los cinco señalados, habríamos de añadir una última atribución llevada a cabo por C. López Álvarez y F. Torrecilla del Olmo en su trabajo «El autor, sus pretensiones y otros aspectos de las Coplas del provincial» ${ }^{19}$, Juan de Mendoza, transmutado en provincial -en opinión de los expresados críticos-, en el texto:

${ }^{16}$ Julio Rodríguez Pú́rtolas, Fray Iñigo de Mendoza y sus Coplas de Vita Christi (Madrid: Gredos, 1968).

17 Marcella Ciceri y Julio Rodríguez Puértolas (eds.), Antón de Montoro. Cancionero (Salamanca: Universidad, 1990).

18 Francisco Cantera Burgos y Carlos Carrete Parrondo (eds.), Antón de Montoro. Cancionero (Madrid, Editora Nacional, 1984).

19 López Álvarez y Torrecilla Del Olmo, «El autor, sus pretensiones y otros aspectos de las Coplas del Provincial», págs. 237-262: 241. 

A fray don Juan de Mendoza
y al señor comendador
que me dan con grande honor
miel, borra, pluma y coroza ${ }^{20}$.

Ambos estudiosos consideran que el autor de la obra debe de ser un cristiano viejo, hastiado y quejoso por el enriquecimiento de los conversos a lo largo de todo el siglo xv, como el citado Juan de Mendoza. De tal modo, según su opinión, la obra se escribió desde el resentimiento contra este grupo social. Ello no explica, sin embargo, por qué la sátira de la obra se extiende a personajes conocidos del poder castellano, cristianos viejos de sangre limpia sin el menor asomo de duda al respecto. Los investigadores reconocen, no obstante, a lo largo de su trabajo, que la anterior equivalencia entre Juan de Mendoza y provincial se pone en cuestión en las propias Coplas, cuando se alude a Juan de Mendoza, no como provincial, sino como un personaje más, también satirizado como el resto:
¿A cómo vale, Molina,
el cuerno que te destroza?
«A fray Duque de Medina
y a fray don Juan de Mendoza ${ }^{21}$.

Considero, por el contrario, que es precisamente dentro del grupo de los conversos donde hemos de buscar al autor de las Coplas del provincial. Es en ese mundo donde ha de situarse la sátira contra los cristianos que contravienen su propia religión -como se trasluce en las Coplas del provincial-, y especialmente contra los judeoconversos que reniegan de sus orígenes a cambio de poder y de dinero, haciendo ascos de su pasado, que el autor de las Coplas nos recuerda caso por caso.

\footnotetext{
${ }^{20}$ Rodríguez Puértolas (ed.), Poesía crítica y satírica del s. XV, pág. 248.

${ }^{21}$ Rodríguez PuÉrtolas (ed.), Poesía crítica y satírica del s. XV, pág. 241.
} 
Menéndez Pelayo ${ }^{22}$-también Antonio Rodríguez Moñino ${ }^{23}$ y Kenneth R. Scholberg ${ }^{24}$ - señaló que la obra quizás fue el resultado de una colaboración entre varios poetas -y por tanto destinada al anonimato-, tomando al pie de la letra lo que dice el poeta madrileño Juan Álvarez Gato en su conocido poema que transcribo a continuación:

Los maldicientes que hicieron las coplas del provencial, porque diciendo mal creen en su merecimiento que dice así:

Unas coplas vi c'an hecho.

Si tal obra va por uso

tales menguas por derecho

suyas son de quien las puso.

Concluyendo va concluso,

sin enmienda repetir,

quien diciendo cuesta ayuso

piensa la cumbre sobir ${ }^{25}$.

Gato alude a «los maldicientes» en plural y luego señala «c'an hecho» también en plural.

Sin embargo, este tipo de colaboraciones, para una pieza de estas características -brutalmente satírica- resulta poco factible por una razón: Si había de permanecer en absoluto secreto su autoría por las posibles represalias que pudiera haber contra quienes la escribieron, es muy difícil que se hiciera en forma cooperativa. De esta opinión son Celestino López Álvarez y Francisco Torrecilla del Olmo, quienes señalan a este respecto que

[...] a nuestro juicio, no cabe pensar en varios autores. El tema es suficientemente comprometido y el ataque lo suficientemente personal como para aventurar que un grupo de personas cultas $-\mathrm{y}$ más en aquella

22 Menéndez Pelayo, Historia de la poesía castellana, tomo II, pág. 298.

23 Antonio Rodríguez MoÑIno, «El cancionero manuscrito de Pedro del Pozo (1547)», Boletín de la Real Academia Española 29 (1949) págs. 453-509: 459.

24 Kenneth R. Scholberg, Sátira e invectiva en la España medieval (Madrid: Gredos, 1971) pág. 336.

25 Emilio Cotarelo y Mori (ed.), Cancionero inédito de Juan Álvarez Gato: poeta madrileño del siglo XV (Madrid: Imprenta de la Revista Española, 1901) pág. 122. 
época- se pusieran de acuerdo en los insultos que debían asestar a la mayoría de la nobleza, pues ésta es la que aparece en las coplas ${ }^{26}$.

Pero, además, el texto de Gato cambia más adelante a singular, cuando dice "suyas son de quien las puso» (no «suyas son de quienes las pusieron») o en los dos últimos versos cuando vuelve a utilizar el singular: «Quien diciendo cuesta Ayuso / Piensa la cumbre sobir». En dichos versos aparece «quien» en lugar de «quienes» y «piensa» en vez de «piensan».

Creo que tan críptica composición, precisamente por ser tan difícil de entender, nos está dando algunas claves para conocer al autor, aunque de forma encubierta. Se trata de un juego literario que obliga al lector a adivinar a qué y a quién se refiere el escritor madrileño.

Los cuatro primeros versos no dicen gran cosa: Gato indica haber «visto»-o se ha enterado; pero, quizás mejor, ha leído la obra- y que la misma hace «menguas» en quien las puso. Esto es: el demérito no es de los aludidos y vilipendiados, sino del autor del poema Obsérvese la oposición de términos jurídicos que hallamos a continuación: «uso / derecho». Y el empleo, otra vez, de tecnicismos que solían aparecer en las sentencias judiciales: «concluyendo» y «concluso». Hay una deliberada abundancia de esta clase de léxico por una razón: Álvarez Gato alude a la gravedad de las acusaciones contenidas en los versos de las Coplas del provincial y a su posible persecución judicial.

Pero lo más revelador viene en los dos últimos versos, cuando se refiere a alguien que primero dice «cuesta ayuso» ('cuesta abajo') y luego piensa en «la cumbre sobir»; o sea, alguien que se contradice entre lo que hace -escribiendo una sátira inmisericorde contra las personas más relevantes del reino- y sus propios deseos de medrar; algo complejo, ciertamente, sin el apoyo y la ayuda de los poderosos que son ridiculizados. Sin duda, Álvarez Gato conoce al autor de la obra y está apuntando hacia él.

En estos dos versos últimos puede verse una clara referencia a uno de los autores citados anteriormente como posible autor: Cota -Rodrigo Cota-. El origen etimológico de la voz CUESTA lo encontramos en

${ }^{26}$ LóPez Álvarez y TorRecilla Del Olmo, «El autor, sus pretensiones y otros aspectos de las Coplas del Provincial», pág. 241. 
COSTA/COTA. Obsérvese además la voz que aparece en un verso anterior: «menguas». Esta se sitúa muy cerca, fonéticamente, de la voz Maguaque, remoquete que se utilizaba para referirse al escritor toledano ${ }^{27}$. De manera que Álvarez Gato nos está diciendo, de manera subrepticia y sin atreverse a hacerlo de forma abierta, el nombre del autor citando sus dos apellidos de forma encubierta (Cota de Maguaque). ¿Por qué causa?

Ambos - Cota y Gato- son judeoconversos ${ }^{28}$. Los dos tienen cargos relevantes durante el reinado de Enrique IV. Se conocen bien y viven muy cerca: Cota en Toledo, como jurado del ayuntamiento; y Juan Álvarez en Madrid, al servicio entonces de Pedrarias Dávila -o Pedro Arias de Ávila-, hijo de Diego Dávila, tesorero del rey Enrique IV. Y ambos son miembros de familias importantes. El padre de Rodrigo Cota, Alonso Cota, conseguirá una buena posición social como recaudador de tributos en la ciudad de Toledo, heredando su posición su primogénito, el escritor y jurado Rodrigo Cota. Y Juan Álvarez Gato, descendiente del primer «Gato» que subió la muralla de Madrid contra los moros durante la Reconquista, ostentó, como su familia, una posición social y económica acomodada, acabando sus años como ayudante y persona de confianza de Isabel la Católica. Pero, además, los dos son escritores.

¿Qué tiene en contra de Rodrigo Cota el escritor madrileño para aludir a él, aunque fuera de una manera tan críptica, como autor de las Coplas del provincial?

Mucho tiene que ver la peculiar relación de ambos con una de las familias más poderosas de la época, la de los Arias Dávila, de Segovia. Diego Arias Dávila, como tesorero del reino, acumulará grandes riquezas y un enorme poder, el cual heredará su primogénito, Pedrarias, al que

27 Francisco Cantera Burgos, El poeta Ruy Sánchez Cota (Rodrigo Cota) y su familia de judios conversos (Madrid: Consejo Superior de Investigaciones Científicas, 1970).

28 Sobre Álvarez Gato, véase Francisco Márquez Villanueva, Investigaciones sobre Juan Álvarez Gato. Contribución al conocimiento de la literatura castellana del siglo XV (Madrid: Real Academia Española, 1960). Sobre Cota, se ha reeditado el veterano trabajo de Francisco Cantera Burgos (1970) en nueva edición, ampliada con otros dos estudios: El poeta Rodrigo Cota y su familia. Otros dos estudios sobre cancioneros. Presentación de Javier Castaño (Miranda de Ebro: Fundación Cultural profesor Cantera Burgos, 2011). 
sirve como mano derecha Álvarez Gato ${ }^{29}$. Pedrarias casó en primer lugar con María Ortiz de Valdivielso, la cual falleció sin dejar descendencia ${ }^{30}$. Y tiempo más tarde se volvió a casar, ya viudo, con una hermana de Rodrigo Cota, María Ortiz Cota, con la que tuvo al menos ocho hijos.

La causa de la mala relación de Rodrigo Cota con la familia de su hermana la podemos encontrar en las Coplas del provincial, concretamente en los siguientes versos:

¿Quién es la dama afeitada?

A vos digo, fray montero:

«la de nuestro tesorero,

que anda en vida embalsamada».

¡Válame la Trinidad,

que yo no caía en ella;

esa es la que desuella

a vuestra paternidad! ${ }^{31}$

En los anteriores versos se habla con desprecio de la mujer de «nuestro tesorero»-entonces Diego Arias Dávila- María Palomeque, con quien este se casó en 1465, fecha de escritura de la obra, como ya he señalado. Este se había casado previamente con Juana Rodríguez, con quien no tuvo hijos, y luego de esta con Elvira González, madre de sus tres hijos (el citado Pedrarias, primogénito, Isabel, la única hija, y el luego obispo de Segovia, Juan Arias Dávila), también fallecida.

Por lo que parece, María Palomeque tenía algo pendiente con Rodrigo Cota en función de lo que se señala en los anteriores versos: «esa es la que desuella / a vuestra paternidad». Y el autor de las Coplas del provincial no la deja muy bien parada: dice que está afeitada» en el sentido

${ }^{29}$ Sobre Diego Arias y su familia, y especialmente sobre la persecución inquisitorial que sufrieron, véase Carlos Carrete Parrondo, Proceso inquisitorial contra los Arias Dávila segovianos. Un enfrentamiento social entre judios y conversos (Salamanca: Universidad Pontificia de Salamanca, 1986).

30 María Eugenia Contreras JimÉnez, Linaje y transición histórica: los Arias Dávila entre el medievo y la modernidad (Madrid: Universidad Complutense, 2018) pág. 114.

${ }^{31}$ Rodríguez Puértolas (ed.), Poesía crítica y satírica del s. XV, pág. 261. 
de que su cara estaba llena de afeites para disimular su edad, pues sabemos que para entonces -1465 , fecha de su matrimonio con el tesorero Diego Arias- ya era abuela de un niño llamado «Luxanico» ${ }^{32}$. Por tal razón dice a continuación que «anda en vida embalsamada».

Las referencias son tan evidentes, que no hace falta ser muy perspicaz para apercibirse de quiénes son los aludidos: «tesorero» (Diego Arias Dávila), la «dama afeitada» y «embalsamada» (María Palomeque), «vuestra paternidad» (Rodrigo Cota, investido como provincial de la orden). ¿Puede quedar alguna duda, con tales datos, de la autoría de la obra? La referencia tan directa al «tesorero» y a su esposa, así como el verbo «desuella» dirigido contra «vuestra paternidad» (el provincial, Rodrigo Cota) nos ponen en el buen camino.

Pero en los anteriores versos aparece otra persona, «fray montero», que apenas encubre su nombre real. Se trata, con poco margen de duda, del también poeta, judeoconverso cordobés, Antón de Montoro, también llamado el «Ropero» por tener el oficio humilde de sastre y de vendedor de ropa por las calles, de lo que se burlaron poetas contemporáneos ${ }^{33}$. Cota, en los anteriores versos transcritos de las Coplas del provincial, juega con las dos palabras - montoro y ropero- y crea una forma híbrida: montero. Su aparición en las Coplas del provincial lo invalida, por tanto, como autor de estas.

Fue Antón de Montoro un buen amigo del poeta madrileño Juan Álvarez Gato, el cual le dedicó amables poemas. Sabemos que tanto Gato como Montoro no tuvieron una buena relación con Cota, hombre, a lo que parece, bastante irascible y que mantuvo muchos frentes abiertos con diversos personajes de su época. A este respecto, en un largo poema, Montoro se dirige a Cota en los siguientes términos, con ocasión de la escritura del conocido Epitalamio burlesco, escrito años después de las Coplas del provincial:

Gentilhombre de quien só de quien muchos han querellas

32 Contreras JimÉnez, Linaje y transición histórica, pág. 110.

33 Véase Marithelma Costa, Antón de Montoro (Cleveland: Cleveland State University, 1990) y VV.AA., Homenaje de Antón de Montoro en el V centenario de su muerte (Montoro: Imprenta San Pablo, 1977). 
y mi partecilla, yo

muy de cierto sé que no

me vos tengo de yr con ellas

mas, lindísimo galán,

de buen clarífico trato

do las destreças están

savéis que dice el refrán

muy antiguo «muera gato» ${ }^{34}$.

Los versos transcritos expresan con claridad el carácter bronco y poco amistoso de Rodrigo Cota («de quien muchos han querellas»), señal de que tuvo muchos enfrentamientos a lo largo de su vida. Y aunque reconoce que entre ellos - Cota y Montoro- no ha existido ninguna controversia grave, le advierte de la necesidad de que el resto acabe cuanto antes, usando para ello el refrán que dice «muera gato [y muera harto]». La referencia sin embargo a «gato» está puesta con toda la intención: lo es, presumiblemente, al escritor Juan Álvarez Gato, quien años atrás, en el poema transcrito con anterioridad, ya había dado cuenta de él como autor de las Coplas.

El anterior poema, de Montoro contra Cota, es con ocasión de haber escrito este último el citado Epitalamio burlesco, una durísima composición contra los asistentes, familiares del novio, a la boda de su sobrino Diego Arias Dávila, hijo de su hermana María Ortiz Cota y de su cuñado Pedrarias Dávila, con una familiar de los Hurtado -Marina Hurtado-, por -según se ha dicho- no haber sido invitado ${ }^{35}$. La propia reina Isabel I amonestó a Cota al haberse dirigido ofensivamente contra sus propios familiares, a los que acusaba de lo que él también era, descendiente de judíos. Dijo a este respecto la reina que era «ladrón de casa». Montoro en su poema le amonesta por lo mismo. Y aunque el escritor cordobés reconoce que en algún momento él también pudo ofender a los suyos, lo hizo por estricta necesidad y solo cuando no tuvo más remedio.

34 Ciceri y Rodríguez PuÉrtolas (eds.), Antón de Montoro. Cancionero, pág. 419.

35 Sobre esta composición escribió un interesante trabajo el profesor CANTERA Burgos (El poeta Rodrigo Cota, págs. 74-80); y también Eleazar GutwirTH, «On the background to Cota's Epitalamio burlesco», Romanische Forschungen 97 (1985) págs. 1-14. 
Álvarez Gato le dedicará un poema al poeta cordobés, valorando sus versos y olvidando su pobre condición, quizás en respuesta a Rodrigo Cota:

Trae a consecuencia aquel pobre ropero de Córdoba, Antón de Montoro, y al mozo d'espuelas Mondragón, que fue la causa d'estas coplas, diciendo que si estos obraren o hablaren bien (o otros generalmente) no les debe empachar venir en hábito bajo o pobremente para ser oídos o loados:

No hagamos Dios del oro,

dejemos este aguaducho

si bien obra el de Montoro,

aunque pobre de tesoro

téngale por rico mucho;

pues tomemos conclusión

en esta vida que vuela $[\ldots]^{36}$.

En las Coplas del provincial, el tesorero Diego Arias Dávila aparece retratado de esta forma:

A ti fray Diego Arias, puto, que eres y fuiste Judío; contigo no me disputo, que tienes gran señorío; águila, castillo y cruz dime de dónde te viene, pues que tu pija capuz nunca la tuvo ni tiene.

«El Águila es de San Juan, y el castillo el de Emaús, y en la cruz pusiste a Jesús siendo yo allí capitán ${ }^{37}$.

${ }^{36}$ Cotarelo (ed.), Cancionero inédito, pág. 119.

${ }^{37}$ Rodríguez Puértolas (ed.), Poesía crítica y satírica del s. XV, pág. 245. 
El autor de las Coplas -Rodrigo Cota- se está burlando, en el anterior texto, de Diego Arias, de orígenes judíos, cuyo nombre hebreo fue Isaque Abenacar, convertido de niño por sus padres al cristianismo ${ }^{38}$. Cota lo acusa de lo que él mismo es -judeoconverso-, y de haber crucificado, como judío que era, a Jesús («y en cruz pusiste a Jesús»).

Obsérvese, sin embargo, que Cota no discute el poder de Diego Arias -«que tienes gran señorío», señala-. Efectivamente, se convirtió en el hombre más poderoso de su tiempo, durante la primera mitad -de 1454 a 1464- del reinado de Enrique IV. Puede decirse que la hermana de Rodrigo Cota, María Ortiz Cota, hizo un buen matrimonio con el hijo de Diego Arias, Pedrarias Dávila. Sin embargo, parece que surgió algún inconveniente entre Rodrigo y la nueva esposa de Diego Arias, María Palomeque, suegra de su hermana María Ortiz Cota.

Sin embargo, las Coplas del provincial cuestionan el lícito origen del escudo de la familia («Águila, castillo y cruz, / Dime, ¿de dónde te viene?»), tratándose de una familia de origen judío ${ }^{39}$. Estudios sobre los judíos del XV asentados en la península revelan cómo muchas familias cambiaron sus apellidos, eliminando los nombres judíos o cualquiera otra forma sospechosa o que pudiera delatarlos. Se inventaron orígenes que no correspondían a la realidad. O incluso se trasladaron a otras tierras donde no se les reconociera como judíos. A ello se refiere Francisco I. Quevedo:

Todo lo dicho no significa que siempre fueran usadas estas fórmulas, sino que simplemente la movilidad geográfica y el cambio de apellido fueron una constante en el grupo converso, en ocasiones por pura necesidad -huyendo de las persecuciones del siglo Xv-, pero en otras muchas,

38 Doreen Carvajal, The Forgetting River: A Modern Tale of Survival, Identity, and the Inquisition (London: Penguin Books, 2012) pág. 212.

39 Sabemos que el escudo tiene su origen en 1462, descrito del siguiente modo: «Sean tenudos de se llamar el apellido de mi, el dicho Diego Arias, y sean tenudos de traer e traygan mis armas, que son un escudo figurado en tres partes de esta manera: en la parte de arriba, a la mano derecha, una cruz hueca colorada en campo blanco y en la parte de la mano yzquierda, una aguila en campo blanco y en la parte de avajo un castillo blanco y en la puerta de el un tao turquesado y todo en campo verde, y el dicho escudo es orlado con la orladura en todo el derredor de el»; www.euskalnet.net/laviana/ gen_hispanas/arias_davila.htm. [Consultado el 30/10/2018]. 
para lograr el objetivo de la promoción social, que siempre había de ir acompañada de la ocultación del pasado hebreo ${ }^{40}$.

El poder económico que algunos de ellos alcanzaron les permitió ocultar de mejor forma su ascendencia judía. A este respecto, muchos compraron cargos de juros municipales, o de tesoreros y contadores, en los gobiernos locales de la época, enriqueciéndose progresivamente. Como señala Francisco I. Quevedo:

Fue precisamente esta riqueza la que les permitió a muchos acceder al poder local mediante la compra de oficios. No hemos de olvidar lo perseguida, en teoría, que estaba la presencia de conversos en los cabildos municipales y, en el caso concreto de Córdoba, principalmente tras los dramáticos sucesos de la Cruz del Rastro (1473). Antes de aquellos acontecimientos, dicen las crónicas que «Entre ellos había grandes enemistades e grande envidia, como los cristianos nuevos de aquella cibdad estoviesen muy ricos, y les viesen de contino comprar oficios, de los cuales usaban soberbiosamente, de tal manera que los cristianos viejos no la podían conportar» ${ }^{41}$.

Cota, por tanto, en las Coplas del provincial se refiere con desprecio a Diego Arias, como acabamos de ver. También a la reciente esposa de este, María Palomeque. Y en otros versos trata de forma satírica a su hijo pequeño, el joven obispo de Segovia Juan Arias Dávila:
A ti, fray Juan Baharí,
gran pontífice mundario,
rezador del Genesí
mejor que del calendario,
así yo de ti vea gozo,
obispo talle de cuero,
que te vi siendo más mozo
oficial de un cuchillero ${ }^{42}$.

40 «Engaño genealógico y ascenso social. los judeoconversos cordobeses»; https:// ifc.dpz.es/recursos/publicaciones/33/01/59quevedo.pdf [Consultado el 30/10/2018].

41 «Engaño genealógico y ascenso social. Los judeoconversos cordobeses»; https:// ifc.dpz.es/recursos/publicaciones/33/01/59quevedo.pdf [Consultado el 30/10/2018].

42 Rodríguez Puértolas (ed.), Poesía crítica y satírica del s. XV, pág. 251. 
Parece que, en la época, el obispo de Segovia Juan Arias tenía como sobrenombre «Baharí», palabra de origen árabe que aludía a una clase de pájaro; aunque en lenguaje de germanías tal término significaba 'ladrón' ${ }^{43}$. Probablemente, en este sentido, alude Cota a este en sus Coplas, acusándolo por tanto gravemente. Por otra parte, la referencia a «talle de cuero» o a haber sido de joven "oficial de un cuchillero» no queda muy clara, posiblemente alude a su vida disoluta en sus primeros años. Juan Arias (1436-1497), obispo de la ciudad de Segovia desde 1461, fue el introductor de la imprenta en España, pues bajo su mandato el tipógrafo Juan Párix llevó a cabo el primer libro impreso en nuestro país en 1472, el Sinodal de Aguilafuente.

Ninguna otra familia es tan perseguida y tratada tan despectivamente en la obra como los Arias Dávila en tres partes diferentes de la misma y sobre tres individuos (Diego Arias, María Palomeque y el obispo Juan Arias). El único miembro que no aparece como objeto de sátira en el texto es el hijo mayor y heredero, Pedrarias, cuñado de Rodrigo Cota, quizás por respeto a su propia hermana, María Ortiz Cota, con la que acababa de casar en aquellas fechas.

Con el tiempo, sin embargo, también la descendencia de Pedrarias Dávila y su propia hermana, e incluso su fallecido esposo, serán objeto del escarnio por Rodrigo Cota en el ya referido Epitalamio burlesco, años después de la escritura de las Coplas del provincial.

Saldrá entonces, alabando los hechos y memoria de Pedrarias, Antón de Montoro, el Ropero, en un largo poema donde recordará las virtudes del hijo mayor de Diego Arias Dávila:

Y si me decís por qué tan locamente me fundo, mi señor, yo os lo diré: qu'el señor Pedrarias fue el fénix de aqueste mundo; nosotros, en general, quien más hazen de valía,

43 Francisca Medina Morales, El léxico de la novela picaresca (Málaga: Universidad de Málaga, 2005) pág. 40. 
buena aguja y buen dedal,

gran banasto de retal,

botica de espeçería ${ }^{44}$.

Hay, por tanto, fundados argumentos para atribuir la escritura de la obra a Rodrigo Cota. La declaración de Álvarez Gato -en clara defensa de los Arias segovianos, tan atacados en las Coplas-, las referencias de Antón de Montoro a las múltiples «querellas» que tenía Rodrigo Cota con muchos individuos y las tres ocasiones diferentes en que aparece la familia Arias Dávila en la obra (sátiras, en este orden, de Diego Arias, de María Palomeque y del obispo Juan Arias) son argumentos bastantes para conceder la paternidad de la misma a Rodrigo Cota. La causa de su animadversión se explica en la propia obra, cuando se refiere -como ya he señalado- a María Palomeque: «esa es la que desuella / a vuestra paternidad». Volverá de nuevo Cota a hacer objeto de su escarnio al heredero y primogénito de Pedrarias Dávila, sobrino carnal de Rodrigo Cota, en el Epitalamio burlesco.

Por otra parte, en las Coplas aparece una sátira de la familia Sandoval, concretamente del conde de Treviño, Manrique de Sandoval. En el momento de la escritura de la obra, Cota está casado con Isabel de Sandoval, hija de Juan de Sandoval y de María de Toledo, de linaje noble en ambos casos. Isabel moriría en 1477. ¿Está ridiculizando en los siguientes versos a los familiares de su mujer? No puedo afirmarlo con rotundidad, pero no sería nada extraño. Dice así:

De Treviño fraile y conde,

Manrique de Sandoval,

la verdad nunca se esconde,

bien la sabe el Provincial,

que de hoy más, por el escote,

podéis poner por reseña;

no os podrán poner por mote

«hijo de la casta dueña» ${ }^{45}$.

\footnotetext{
${ }^{44}$ Ciceri y Rodríguez Puértolas (eds.), Antón de Montoro. Cancionero, pág.170.

45 Parece que doña María de Sandoval, madre del conde de Treviño, viuda desde hacía años del adelantado Pedro Manrique, llevó una vida bastante licenciosa, lo que 


\section{CAUSA Y RAZÓN DE LA ESCRITURA DE LA OBRA}

De la lectura de la obra no se puede derivar que su autor, Cota, tuviera un objetivo concreto porque nada dice al respecto. ¿Se trata de un puro juego literario? ¿Quizás una reivindicación de los judeoconversos, o incluso de los judíos frente a los nobles y poderosos que gobiernan? ¿O es quizás -como las Coplas de Mingo Revulgo- una sátira contra los poderosos a causa de la situación, extremadamente grave, de Castilla? ¿Quizás, como han dicho algunos críticos, es una sátira de un cristiano viejo contra los judeoconversos? El autor no deja claro que persiga un fin de los anteriormente planteados. Antes bien, parece que, simplemente, se regodea en una crítica muy personal a la práctica totalidad de los personajes que detentan el poder en aquellos momentos en Castilla, de los cuales da siempre una perfecta identificación. En este sentido, se nota su especial inquina contra los Arias Dávila por razones ya expuestas. Pero muy probablemente también existan circunstancias de su sátira que solo podríamos explicar con un conocimiento profundo de su biografía, algo de lo que, hoy por hoy, por desgracia, no disponemos.

Sin embargo, creo que hemos de derivar la cuestión no tanto hacia planteamientos parciales o personales, de la inquina del propio Cota contra muchos de los que satiriza en sus versos. De hecho, el que la obra se escriba en 1465, año especialmente conflictivo a nivel político, puede explicar su génesis, o al menos darnos algunas pistas a este respecto.

Si situamos su escritura en la primavera de 1465, antes por tanto de los hechos ocurridos en la farsa de Ávila -5 de junio de aquel año-, hay una circunstancia histórica previa muy próxima que provocó un terremoto de graves consecuencias y que fue el desencadenante de muchas de las cosas que luego ocurrieron. Me refiero a la sentencia de Medina del Campo, hecha pública el 16 de enero de aquel año. Se trata de una sentencia arbitral promovida por gran parte de la nobleza enfrentada al rey Enrique IV, la llamada Liga de Nobles encabezada por Juan Pacheco, en un momento de debilidad del rey de Castilla, tras el alejamiento de la corte de Beltrán de la Cueva. Son más de cien medidas, muchas de

provocó el escándalo entre la nobleza. Su hijo la llegó a encarcelar, según Luis SALAZAR y CAstro (Historia genealógica de la casa de Lara [Madrid: Imprenta Real, 1697] tomo II, pág. 69). 
ellas dictadas contra los judíos ${ }^{46}$. Se establecía, por ejemplo, que debían vivir apartados del resto de la población en guetos, debiendo portar un distintivo para identificarlos, prohibiéndoseles llevar ropa de seda o jubones. Se les impedía desempeñar cargos palaciegos, ejercer la actividad de abogados y se les limitaba cualquier acceso a los cargos que habitualmente desempeñaban dentro de la administración. Se prohibía también la construcción de sinagogas. Enrique IV se opuso a la sentencia y la Liga de Nobles promovió su destronamiento, nombrando como nuevo rey al, entonces todavía niño, Alfonso el Inocente, en la llamada Farsa de Ávila, junio de 1465.

Dichos nobles, tras la muerte de Alfonso (1468), apoyarán a la infanta Isabel frente a Juana la Beltraneja, los mismos nobles que apoyaron encendidamente la sentencia de Medina del Campo del 16 de enero de 1465. Isabel supo pronto que tenía una deuda que pagarles por su apoyo y que estos se cobrarían con la expulsión de los judíos en 1492.

Cota sabe que muchos de los que apoyan a dicha Liga de Nobles son judeoconversos como él que se esfuerzan porque no quede ningún rastro de sus orígenes semitas. Entre otros, los Arias Dávila, pero también Torquemada, como máximo ejemplo de lo que vengo expresando. El propio Antón de Montoro nos reveló en sentidos versos cómo su deseo fue que nadie pudiera recordarle que era descendiente de judíos:

¡O, Ropero amargo, triste

que no sientes tu dolor!

Setenta años que naciste

y en todos siempre dixiste:

«ynviolata permansiste»

y nunca juré al Criador.

Hize el Credo y adorar

ollas de tocino grueso,

torreznos a medio asar,

oyr misas y reçar,

santiguar y persinar,

46 José Belmonte Díaz y Pilar Leseduarte, La expulsión de los judios: auge y ocaso del judaísmo en Sefarad (Bilbao: Ediciones Beta, 2007) pág. 158. 
y nunca pude matar

este rastro de confeso ${ }^{47}$.

Lo más triste de todo es que, al igual que el Ropero, una gran mayoría de judeoconversos quiso «matar el resto de confeso» que pudiera quedar en ellos.

Las Coplas del provincial están escritas desde el resentimiento de un judeoconverso que acusa a cristianos poderosísimos de incumplir las normas sagradas de su religión. Por ello se inviste de provincial o visitador $\mathrm{y}$, haciendo más grave su pecado, convierte a los nobles en frailes. El desfile de cornudos, sodomitas, prostitutas, bígamos y de situaciones incestuosas y de otro tipo los convierte en hipócritas puestos al descubierto con nombre y apellidos por el autor de las Coplas del provincial.

Pero la sátira de aquellos que ocultan su origen judío es, quizás, más dura todavía. Cota asume una postura firme en contra de ellos. La obra está anticipando lo que volverá a hacer nuevamente con ocasión de la boda de su sobrino Diego Arias con una Mendoza en el Epitalamio burlesco, donde revela el nombre y la progenie hebrea de la familia del novio, en su boda con una cristiana vieja, de la familia de los Mendoza.

La postura de muchos judeoconversos fue muy curiosa. La mayoría apoyó sin fisuras las posiciones antijudías y se decantó por el bando de Alfonso el Inocente y, luego, por el de Isabel de Castilla. Por ejemplo, el poeta Juan Álvarez Gato, servidor de Pedrarias Dávila, quien siguió a su señor cuando se decidió por reivindicar como rey al jovencísimo Alfonso. Muchos otros hicieron lo mismo, por miedo a perder sus privilegios y sus puestos como juros, contadores, etc. en los ayuntamientos de Castilla. Obispos como Juan Arias Dávila, pero también gran cantidad de clérigos, no tuvieron ningún inconveniente en mostrarse partidarios de las medidas que, finalmente, Isabel I tendrá que promover en pago al apoyo de la Liga de Nobles. Ciertamente, la muerte de Alfonso en 1468 hizo que muchos volvieran a la causa de Enrique IV, pero será algo momentáneo. Tras su muerte, en 1474, las antiguas reivindicaciones antijudías se volverán a poner de nuevo sobre la mesa, incluso con mayor fuerza. Y los judeoconversos se mostrarán como los más antijudíos de todos.

47 Ciceri y Rodríguez PuÉrtolas (eds.), Antón de Montoro. Cancionero, pág. 70. 
No puede entenderse la génesis de las Coplas del provincial sin la aludida sentencia de Medina del Campo de enero de 1465. Bajo mi punto de vista, es el desencadenante de su escritura por Rodrigo Cota. Este decidió dar un escarmiento a la nobleza que amenazaba a los de su clase, y especialmente a los judeoconversos que apoyaron la persecución a los de su propia sangre.

\section{LAS COPLAS DEL PROVINCIAL EN RELACIÓN CON LAS OBRAS CONOCIDAS DE RODRIGO COTA}

No son, por desgracia, muchas las obras que conocemos de Rodrigo Cota, reducidas al bellísimo poema Diálogo entre el Amor y un viejo y su Epitalamio burlesco. Menéndez Pelayo consideró que la primera es una de las más bellas composiciones escritas durante el siglo Xv. Por ello creyó que no podía ser Cota, autor de la anterior, quien escribiera una obra como las Coplas del provincial, tan absolutamente distintas en cuanto a estilo, forma, intención, etc.

Sin embargo, y dejando al margen la diferente temática de ambas obras -las Coplas del provincial y el Diálogo entre el amor y un viejo ${ }^{48}$-, hay una multitud de elementos estilísticos y lingüísticos que aproximan a ambas. El primero de ellos es la abundancia de interrogaciones en las dos. En una, el viejo pregunta constantemente al amor; y en la otra, es el provincial quien idea un discurso apoyado en sucesivas preguntas a los nobles que resultan ridiculizados en sus respuestas. Muchas son retóricas; pero otras no ${ }^{49}$.

${ }^{48}$ Entre las ediciones actuales, contamos con la de Elisa Aragone Firenze (ed.), Rodrigo de Cota. Diálogo entre el Amor y un viejo, (s.1.: Le Monnie, 1961) y la de Enzo FRANCHINI, «Diálogo entre el amor y un viejo (Rodrigo Cota)», en Los debates literarios de la Edad Media (Madrid: Ediciones del Laberinto, 2001) págs. 178-193. Un buen estudio comparativo de la obra es el de Nathalie Kasselis-Smith, Los juegos del amor $y$ del lenguaje en la obra de Antón de Montoro, Rodrigo de Cota y Fernando de Rojas (Madrid: Pliegos, 2004). Cito por la excelente versión digital del Dutton Corpus accesible en: http://cancionerovirtual.liv.ac.uk/AnaServer?dutton $+0+$ start.anv $+\mathrm{ms}=11 \& \mathrm{sms}=$ CG\&item=125\&entry=ID6103\#11CG125ID6103 [Consultado el 12/04/2019]. En adelante: $D L$.

49 Los ejemplos en las Coplas del provincial son abundantísimos (RoDRíGuez PuÉrtolas [ed.], Poesía crítica y satírica del s. $X V$ ): «¿A cómo vale el ardor/que traéis 
Otro elemento estilístico que hallamos en ambas es la estructura «ni... ni...», de manera que se suceden las negaciones -del viejo en un caso y de los nobles en el otro- ante las preguntas intimidatorias de amor y del provincial ${ }^{50}$.

En ambos textos, encontramos la presencia abrumadora de la primera $y$, especialmente, de la segunda persona. Son tan abundantes en ambos casos, que apenas dejan espacio a la tercera persona. En los dos, se establece un diálogo entre los personajes que intervienen (el amor y el viejo; el provincial y cada uno de los nobles o dignidades que hablan con él). El tono de confidencialidad es muy evidente tanto en una obra como en la otra ${ }^{51}$.

Es digno de subrayar también, como coincidencia en ambas obras, la abundancia de enumeraciones, especialmente en algunos momentos singulares del Diálogo entre el amor y un viejo ${ }^{52}$.

El rasgo que quizás mejor caracteriza sobre cualquier otro a las Coplas del provincial es la abundancia de voces peyorativas y cercanas a lo soez. Son abundantísimas. En el Diálogo entre el amor y un viejo,

en vuestra silla» (pág. 237) o «¿A cómo vale, Molina/ el cuerno que te destroza?» (pág. 241). También en el Diálogo: «¿A qué vienes? ¿Por dó entraste?/ Di, ladrón, ¿por do saltaste/ las paredes de mi huerta?» (DL, vv. 2-4).

${ }^{50}$ En las Coplas del provincial hallamos ejemplos (RodríGuez PuérTolas [ed.], Poesía crítica y satírica del s. XV) como estos: «ni se acabe, ni se abaje» (pág. 238), «mas no tiene pies ni manos» (pág. 240), «ni águila ni cabrón» (pág. 242), «no os hagáis sordo ni mudo» (pág. 253). En el Diálogo son muy abundantes, pero me permito transcribir los siguientes versos: «ni las ordenadas calles, ni los muros de jazmín, /ni los arroyos corrientes, /de vivas aguas notables, /ni las albercas y fuentes, /ni las aves producientes» (DL, vv. 21-26).

51 En las Coplas del provincial (RodríGuez PuÉRTOLAs [ed.], Poesía crítica y satírica del s. $X V$ ) abunda la estructura en segunda persona del tipo «A ti»: «A ti, fraile mal cristiano» (pág. 238), «A ti, conde Cascorvillo» (pág. 239), «A vos, fray conde real» (pág. 239), etc. Y en el Dialogo hallamos un empleo similar, abundantísimo, ya desde los primeros versos: «Ni tú ni tus servidores /podés bien estar conmigo/ que aunque estén llenos de flores/ yo sé bien cuántos dolores/ ellos traen siempre conmigo » ( $D L$, vv. 41-45).

52 Véase este ejemplo del Diálogo: «Tú hallas las tristes yerbas/ y tú los tristes potajes,/ tú mestizas los linajes, /tú limpieza no conservas, /tú doctrinas de malicia, /tú quebrantas lealtad, /tú con tu carnal codicia, /tú vas contra pudicicia/ sin freno de honestidad» $(D L$, vv. 397-405). 
pese a lo expresado por Menéndez Pelayo, también están presentes a lo largo de todo el texto. Véanse estos ejemplos:

Ve day pan de çaraças

vete carne de señuelo

vete mal ceuo de anzuelo

tira alla que membaraças

Reclamo de paxarero

falso cerro de vallena

el qu'es cauto marinero

no se vence muy ligero

del cantar de la serena ${ }^{53}$.

En otros momentos, el autor del Diálogo entre el amor y un viejo recurre a las metáforas cargadas de acusaciones y a un léxico lleno de connotaciones negativas, como en las Coplas del provincial:

Mira tu negro garguero

de pesgo seco pegado

quán crudio y arrugado

tienes viejo triste el cuero

Mira en esse ronco pecho

cómo el huelfago t'escarua

mira tu ressollo estrecho

que no escupes más derecho

de quanto t'ensuzias la barua.

Viejo triste entre los viejos

que de amores te atormentas

mira cómo tus artejos

parescen sartas de cuentas

Y las vñas tan crescidas

y los pies llenos de callos

y tus carnes consumidas

${ }^{53} D L$, vv. 123-131. 
$\mathrm{y}$ tus piernas encogidas

quales son para cauallos ${ }^{54}$.

En ambas obras se emplea la voz «cuero» en lugar de cuerpo, una suerte de forma metonímica donde se sustituye el contenido por el continente. Véase el ejemplo anteriormente transcrito del Diálogo («tienes, viejo triste, el cuero») o este otro ejemplo de las Coplas del provincial, al referirse a Juan Baharí (el obispo Juan Arias Dávila) en el texto previamente transcrito: «obispo talle de cuero».

Llama la atención la circunstancia de que en ambos textos abunda la forma consecutiva «pues», característica de un lenguaje argumentativo y no tanto de las composiciones poéticas. La localizamos en muchas ocasiones en ambos textos. Aparece en ocho ocasiones en el Diálogo y en dieciséis en las Coplas.

En las Coplas encontramos la forma culta cónclave, refiriéndose su autor a la reunión del provincial con los clérigos ${ }^{55}$. En el Diálogo aparece cóncave en el siguiente verso: «y en los muy hondos cóncaves» ${ }^{56}$. Lo anoto por lo extraña. No la localizo en el $D L E$ ni en ningún otro texto. El CORDE no lo registra hasta el siglo XVIII en un texto de Diego Ignacio de Góngora («hize cortar del trozo menor, porque ajustase a el cóncave de la caja, que había salido algo más corta») ${ }^{57}$.

En diversas ocasiones, tanto las Coplas como el Diálogo inician versos con la forma «A ti», deixis personal que constituye un marcador que busca enfatizar el discurso. Este tipo de deixis es muy abundante en las dos composiciones poéticas. Casi siempre se procede de la misma manera. En las Coplas, el provincial hace una breve presentación del personaje requerido - deixis personal-y a continuación le hace una pregunta, respondiendo luego el interpelado. A continuación, el provincial emite una suerte de juicio o conclusión degradante del individuo en cuestión. En el Diálogo, dado que se trata de dos únicos personajes que dialogan, la estructura no es la misma. Parece una

\footnotetext{
${ }^{54} D L$, vv. 582-599.

55 Rodríguez Puértolas (ed.), Poesía crítica y satírica del s. XV, pág. 244.

${ }^{56} D L$, v. 326.

57 http://corpus.rae.es/cordenet.html. [Consultado el 30/10/2018].
} 
suerte de disputatio según el viejo esquema medieval, actualizado conforme a lo que luego señalo. Aparece, como en las Coplas, la deixis personal, que da lugar a requiebros, respuestas de uno y de otro, sin que tengamos un claro vencedor. Solo al final del texto, cuando la última palabra la tiene el viejo, podemos entender su victoria frente a las servidumbres del amor.

En todo caso, el Diálogo entre el amor y un viejo, tan medieval en tantos aspectos, es sin duda una pieza anticancioneril, escrita bajo el dictado del amor cortés, pero también en contra de los presupuestos de este tipo de literatura. No extraña que se le intentara adjudicar a Cota la autoría del primer acto de La Celestina. Al fin y al cabo, esta escribe el epitafio de toda una época, de la lírica provenzal que inundó los cancioneros del xv. El diálogo del amor está más cerca del mundo del entremés, avant la lettre, a este respecto; $\mathrm{y}$, por tanto, tiene un marcado tono realista, en su sátira de los viejos enamorados y de los afeites de las ancianas que no asumen el paso del tiempo.

También las Coplas del provincial nos muestran ejemplos de mujeres ridículas, llenas de afeites pese a su edad, como en el caso de la descripción que se hace de María Palomeque. O de esta otra dama:
A ti, diosa del deleite, gran señora de vasallos, dícenme que tienes callos en el rostro del afeite, y que vuestra señoría tiene tres dientes postizos que sabe mucho de hechizos y estudia nigromancía ${ }^{58}$.

Sin que podamos llegar a afirmar que el Diálogo es una obra satírica ni cáustica como las Coplas, sin embargo nos va aproximando a una literatura de raíz realista, alejada de la lírica cancioneril y del amor cortés.

${ }^{58}$ Rodríguez PuÉrtolas (ed.), Poesía critica y satírica del s. XV, pág. 254. 
La comparación con el Epitalamio burlesco ${ }^{59}$ es todavía más interesante. Esta última comienza con una exclamación: «Pergonçalez, Pergonçalez». Tal llamada de atención al que parece ser familiar de la novia se completa luego con un alegato religioso, «dad acá con bendición», a causa de la próxima boda de la novia cristiana y del novio judío. La persona que se invoca es, en realidad, el obispo Pedro González de Mendoza ${ }^{60}$, hermano del padre de la novia, D. Diego Hurtado de Mendoza, tercer duque del Infantado. Pedro González llegará a ser tiempo más tarde arzobispo de Toledo, cardenal e incluso se le llamó el «tercer rey», por tener tanto poder como Isabel y Fernando.

De tal familia, Cota llega a decir cosas muy feas en las Coplas del provincial. En primer lugar:

A fray don Juan de Mendoza, y al señor comendador, que me dan, con grande honor miel, borra, pluma y coroza ${ }^{61}$. También lo siguiente: «Al precio de los de Hurtado, que le pone su mujer doña Sancha de Alcozer con un fraile consagrado» ${ }^{62}$.

$\mathrm{Y}$, finalmente:

Una nueva me ha venido, que doña Isabel Hurtado encornuda à su marido con don Pedro su cuñado ${ }^{63}$.

59 Cito por la excelente edición digital del Dutton Corpus: http://cancionerovirtual. liv.ac.uk/AnaServer?dutton $+0+$ start.anv $+\mathrm{ms}=\mathrm{MN} \& \mathrm{sms}=15 \&$ item $=23 \&$ entry=ID2804\& view=compare. [Consultado el 30/10/2018]. En adelante: $E B$.

${ }^{60}$ Véase Francisco Javier Villalba Ruiz de Toledo, El Cardenal Mendoza (14281495) (Madrid: Rialp, 1988).

${ }^{61}$ Rodríguez Puértolas (ed.), Poesía crítica y satírica del s. XV, pág. 248.

${ }^{62}$ Rodríguez Puértolas (ed.), Poesía crítica y satírica del s. XV, pág. 257.

${ }^{63}$ Rodríguez Puértolas (ed.), Poesía crítica y satírica del s. XV, pág.261. 
¿Recordaba Cota, cuando componía el Epitalamio burlesco, los anteriores versos? Sin duda. De hecho, el Epitalamio cuenta su trato, cuando era una niña, con Marina, hija de Diego Hurtado de Mendoza:

¿Cuerda sos Aldonça en c'año?

año de cinquenta y dos

quando fezimos yo y vos

al del garico el engaño

¿y al hebelve de Alcalá?

Que s'trabe por los cabellos

mira si'm acordará

¡qué negros mundos aquellos! ${ }^{64}$.

Cota sitúa sus recuerdos en 1452 -antes alude a otros de 1450 y 1451 - con gran precisión. Cierto es que cambia los nombres de los novios - de Marina por Aldonza, como el de su sobrino Diego por Manuel-. Y, además de recordar los orígenes judíos de su sobrino y de toda su progenie (menciones a los Cahal, Abenxuxen, Abenhanias, Sophonias y Cohen), alude insistentemente a la comida judía de la boda y al aborrecido tocino de cerdo. No olvida a su cuñado, el fallecido Pedrarias Dávila, al que recrimina que anduvo en vida mucho más interesado por los negocios que por observar los usos de su religión.

Lo más relevante del Epitalamio es el tono de triste despedida de una época de alegría y de felicidad para los judíos. Cota se entristece cuando recuerda la feliz vida de aquellos en el pasado:

Qué son de las çurumbías

de cas de nuestras agüelas.

El placer, las donosías

aquel heruir de caçuelas

Mas, ¿do las alcamonías

que's vendínn al solarejo?

Así se passan los días

iguayam guaf, que m'fago viejo! ${ }^{65}$.

${ }^{64} E B$, vv. $138-145$.

65 EB, vv. 147-154. 
Cierto que tal sentimiento lo mezcla con la sensación de que se va haciendo mayor, al modo que hallamos en el Diálogo del amor y un viejo. Pero su recuerdo de tiempos más felices, cuando todo era fácil para los judíos, se mezcla con su sensación de paso del tiempo.

Hay una evidente relación del Epitalamio burlesco en la forma de tratar el tema judío con las Coplas del provincial. En el Epitalamio, Cota toma un punto de vista nostálgico, pero en todo caso reivindicativo de sus orígenes hebreos, recordando la progenie judía de su sobrino por las dos partes (los Arias Dávila y los Cota), las comidas en las bodas judías, los tiempos felices del pasado. Mientras que en las Coplas se satiriza a los enriquecidos judeoconversos que olvidan su procedencia, y la maldicen, anteponiendo privilegios actuales, posición social y dinero.

También el Epitalamio, como las Coplas, está lleno de voces peyorativas: «negro» («Negro fijo de coquel [...] / negro sea quien mal lo quier») ${ }^{66}$, «mezquino» («que lo vio ni olió el mezquino») ${ }^{67} \mathrm{o}$ cuando trata despectivamente a su cuñado, Pedrarias Dávila, ya fallecido de «arrendador de minucias» ${ }^{68}$. Al padre de la novia lo llama «zorrillo» (dice «a la hija del zorrillo», refiriéndose a la novia) ${ }^{69}$. De Pedrarias, muerto cuando escribe la composición, dice cosas realmente ofensivas:
Así que era su padre agudo
con vnas gramayas rotas,
que por atacar las botas
al albor salí desnudo.
Desgañaba sobr'un figo
qué feruor y qué femencia
que nunca fizo abenencia
sin gallina, queso o trigo ${ }^{70}$.

\footnotetext{
${ }^{66} E B$, vv. $106-107$

${ }^{67} E B, \mathrm{v} 89$.

$68 E B, \mathrm{v} 76$.

${ }^{69} E B$, v. 83.

${ }^{70} E B$, vv. 50-57.
} 
Sabemos que Cota llegó a demandar a su hermana y a sus sobrinos, como herederos de Pedrarias Dávila, pues este último no devolvió en vida un dinero que le prestaron su cuñado Rodrigo y su suegro Francisco Cota. Tal circunstancia pudo acrecentar las diferencias que previamente debieron de existir y trajo el enfado y el ataque literario de Cota con su Epitalamio burlesco. Dicho pleito es de fecha 8 de enero de 1480 y se conserva en el archivo de la Real Chancillería de los reyes de Castilla: «Apercibimiento a los herederos de Pedro Arias de Ávila, a petición de Rodrigo Cota, hijo del jurado Francisco Cota, para que les paguen las deudas que el dicho Pedro Arias tenía con ambos» ${ }^{71}$.

Entre los términos despectivos del Epitalamio, encontramos «balandrones» ${ }^{72}$, diminutivos con valor ofensivo e incluso llega a decir que la novia tendrá un hijo que será arrendador como su padre y abuelo y también «largo como un filisteo» ${ }^{73}$, con fin claramente despectivo.

Pero donde mejor encontramos la rabia y el insulto de Cota -muy cerca de los términos empleados en las Coplas- es en los siguientes versos, lanzando sus peores deseos para quienes maldicen sus raíces judías:

qu'el Señor nos vengue d'él

que por vida de su agüela

que sale abieso a Ysrael ${ }^{74}$.

Como en las Coplas, no falta la referencia a personas reales. En el Epitalamio aparece su hermana («Yré fablar con mi hermana») ${ }^{75}$, los Mendoza, Pergonçalez, Pero López (supongo que se refiere el alcalde mayor de Toledo, Pero López de Ayala), Antón de Faro -converso toledano- o Clara Gonçalez, además de los novios y su cuñado Pedrarias, ya fallecido, y las familias hebreas citadas: Cahal, Abenxuxen, Abenhanias, Sophonias y Cohen.

71 Archivo de la Real Chancillería de los reyes de Castilla Consejo. ES.47161.AGS// RGS,LEG, 148001,95.

$72 E B, 91$.

${ }^{73} E B, \mathrm{v} 91$.

${ }^{74} E B$, vv. 103-105.

${ }^{75} E B, \mathrm{v} 22$. 
Hay dos momentos que nos recuerdan, en el Epitalamio, a las Coplas del provincial. El primero, cuando Cota usa el término «bahalí» o «bahal»:

Bahal daque'stas peleas

guacara duelos carcoma

ay d'aquellas anazeas

del val de domen coloma $^{76}$.

No vale el mundo vn noben

cada día se empeora

ved qué frito de sartén

bahalí que hazen agora ${ }^{77}$.

Dicho término («bahalí/baharí») se utiliza también en las Coplas del provincial referidas, como ya he señalado, al hermano de Pedrarias, el obispo de Segovia, Juan Arias Dávila, tratado despectivamente como ladrón.

Y, como en las Coplas, ahora aparece un verso en el Epitalamio que parece copiado de aquellas, en la referencia a quienes llegan de Segovia:

Tomad aquesta altamía

y lleuásela a la nouia

y dezid que se la enbia

su tía, que vien de Segobia ${ }^{78}$

Las alusiones a la ida o venida de Segovia aparecen así en las Coplas:

que por vida de la novia

hermosa en el presumir,

que son idos a Segovia

por cosas para os decir.

Los de Segovia han llegado

con las cosas que allá hallaron,

y al Provincial admiraron

luego que las han contado ${ }^{79}$.

${ }^{76} E B$, vv. 122-125.

$77 E B$, vv. 210-213.

78 EB, vv. 178-181.

79 Rodríguez PuÉrtolas (ed.), Poesía crítica y satírica del s. XV, pág. 254. 
Son, por tanto, muchas las similitudes lingüísticas (uso de formas despectivas, lenguaje enfático, referencias a personas reales -especialmente los Mendoza y los Arias Dávila-, uso de la voz «bahalí/baharí», o a Segovia). Pero la mayor de todas es la relación con el tema judío. Si el Epitalamio burlesco es un recuerdo de los orígenes de la familia de su sobrino por las dos partes -materna y paterna-, y añoranza de mejores y más felices tiempos pasados, las Coplas son una sátira de muchos judeoconversos que como los propios Arias segovianos maldijeron su progenie hebrea. También, en este caso, de cristianos que pecaban contra su propia religión, de forma hipócrita, a la vez que maldecían a la religión judía.

Sin duda, la sátira mordaz de ambas obras -Epitalamio y Coplas-es similar, así como también el estilo, la provocación y la reacción de Cota ante un mundo que -como supo ver- sería, en adelante, muy difícil para los judíos y para los judeoconversos como cristianos nuevos. El tiempo, por desgracia, le daría la razón. Pocos como él elevaron la voz, alta y clara en su caso, aunque oculto en el anonimato, como no podía ser de otro modo. Mientras, muchos como los que él satiriza en sus obras solo estaban atentos a conservar privilegios y regalías. Y contra ellos, y contra todos los hipócritas nombrados con nombre y apellidos en las dos obras, escribió sus poemas, especialmente las Coplas del provincial.

\section{Conclusiones}

A lo largo de este trabajo he llegado a las siguientes conclusiones:

1. He establecido una fecha de escritura de la obra, próxima a los meses de marzo/abril de 1465. Para llegar a tal conclusión, he situado un terminus ad quem (fallecimiento de Pedro Girón y Diego Arias Dávila a primeros de 1466, que aparecen vivos en la obra) y un terminus a quo: finales de 1464, con el nombramiento del duque de Alburquerque (hasta entonces condado de Alburquerque). La referencia al cercano invierno, así como la falta de alusiones a la farsa de Ávila (junio de 1465), y también la residencia durante dichos meses de abril y mayo del rey con su corte en Madrid, me han servido para fijar un margen temporal muy corto y preciso, situado en los indicados meses. 
2. El espacio en que se sitúa la acción es claramente Madrid. La referencia a la villa en la obra, así como los reiterados períodos que pasó el rey en dicha localidad a lo largo de su reinado permiten situarla allí. También las alusiones a «los de Toledo» recién venidos y la expresión «los de Segovia han llegado» corroboran mi conclusión.

3. He podido demostrar que la obra, en un aparente caos, tiene sin embargo un orden y sigue una clara estructura: por géneros y en cada uno de los casos (hombres y mujeres) según el orden estamental.

4. Tras presentar las diversas atribuciones que se han hecho hasta a seis candidatos a autor de la obra, me decanto por Rodrigo Cota por las siguientes razones:

a) La referencia de Juan Álvarez Gato a Cota en el conocido poema que transcribo en el estudio (cuesta ayuso, menguas) encubre en realidad una alusión a Costa/Cota - etimología de cuesta- y a Maguaque -remoquete con que era conocido el autor-.

b) La sátira de Diego Arias Dávila que aparece en las Coplas acusándolo de tener orígenes judíos. Se trata del poderoso contador mayor del reino, cuyo hijo Pedrarias se casó con su hermana María Ortiz Cota, siendo por tanto este último su cuñado.

c) La sátira en la obra de la reciente esposa de Diego Arias, María Palomeque, de la que se burla por sus afeites y de estar embalsamada, por tratarse de una mujer entrada en años, y abuela.

d) La ridiculización también del hijo pequeño de Diego Arias, Juan Arias, obispo de Segovia apellidado «ladrón» (Bahari) en lenguaje de germanías en las Coplas del provincial. Ninguna otra familia es tan vilipendiada como la de los Arias Dávila, señal inequívoca de la paternidad de la obra.

e) Años más tarde se burlará también de los Arias Dávila por no haber sido invitado a la boda del primogénito de Pedrarias Dávila, con una joven de la familia de los Mendoza.

f) El conocido poema de Antón de Montoro, escrito contra Rodrigo Cota por su Epitalamio burlesco, nos muestra a un hombre, Cota, lleno de «querellas» con muchos individuos, debido a su carácter conflictivo. La alusión encubierta a Álvarez Gato en el mismo 
poema nos recuerda la atribución a Cota que aquel ya hizo años antes a las Coplas del provincial.

5. Establezco la causa que pudo mover a Rodrigo Cota a escribir las Coplas: la sentencia arbitral de Medina del Campo de enero de 1465. Entre las más de cien disposiciones, aparecen muchas en contra de los judíos. Tras dicha sentencia se encuentra la Liga de Nobles, formada por los más poderos aristócratas de su tiempo y muchos judeoconversos que quieren demostrar así su compromiso contra los judíos, defendiendo sus privilegios y su riqueza y reafirmando su condición de cristianos. Contra ellos escribió Cota su obra, y especialmente contra los nuevos nobles y los señores que, como Diego Arias Dávila y su familia, hicieron ascos a sus orígenes y a su sangre judía.

6. Llevo a cabo un análisis literario y lingüístico de las obras conocidas de Rodrigo Cota y de las Coplas del provincial, observando interesantes coincidencias. Por ejemplo, la común presencia de una estructura poética basada en las preguntas y respuestas, tanto en las Coplas como en el Diálogo. También el predominio de la primera y de la segunda persona, y el empleo constante de voces peyorativas o de connotación negativa. Tanto en las Coplas como en el Diálogo abunda la forma consecutiva «pues» característica del lenguaje argumentativo, o la deixis personal «A ti...», así como voces comunes en las Coplas y en el Diálogo: «cuero» como «cuerpo»-forma metonímica-; «cónclave» y «cóncave». Ambas obras, y también el Epitalamio burlesco, se caracterizan por la presencia de un agregado satírico que es muy evidente en las Coplas del provincial, quizás algo más sutil en el Diálogo entre el amor y un viejo. Lo que en realidad subyace en esta última es un ataque contra la literatura del amor cortés y contra la literatura de raíz provenzal: sátira muy cercana a la que aparece en La Celestina.

7. He establecido diversas relaciones de carácter lingüístico de las Coplas y el Epitalamio. Y, en tal sentido, he señalado el uso en ambas obras de formas despectivas («negro», «mezquino», «zorrillo»), de lenguaje enfático, comunes referencias a personas reales -especialmente a los Mendoza y a los Arias Dávila-, a Segovia y el empleo de la voz «bahalí/baharí». En ambos casos, encontramos la sátira feroz contra los judeoconversos que aborrecen sus orígenes judíos, recordando de dónde 
proceden: alusiones a los Cahal, Abenxuxen, Abenhanias, Sophonias y Cohen.

8. La naturaleza realista de las obras conocidas de Cota-Diálogo y Epitalamio- las aproxima sin duda a las Coplas del provincial, con las que comparten no solo la sátira, en forma más o menos descarnada, sino especialmente un concepto mucho menos idealista de la literatura y de la realidad que en los cancioneros de la época y en la novela sentimental, que impusieron un modelo que no encontramos ni en las obras de Cota, ni tampoco en las Coplas del provincial.

Recibido: $16 / 11 / 2018$

Aceptado: 20/04/2019 
